\title{
A Malaria Fingerprint in the Human Genome?
}

\section{Citation}

Daily, Johanna P. and Pardis Sabeti. 2008. A malaria fingerprint in the human genome? New England Journal of Medicine 385(17): 1855-1856.

\section{Published Version}

doi:10.1056/NEJMe0801414

\section{Permanent link}

http://nrs.harvard.edu/urn-3:HUL.InstRepos:6616486

\section{Terms of Use}

This article was downloaded from Harvard University's DASH repository, and is made available under the terms and conditions applicable to Open Access Policy Articles, as set forth at http:// nrs.harvard.edu/urn-3:HUL.InstRepos:dash.current.terms-of-use\#OAP

\section{Share Your Story}

The Harvard community has made this article openly available.

Please share how this access benefits you. Submit a story.

Accessibility 


\section{A Malaria Fingerprint in the Human Genome?}

Johanna P. Daily, M.D., and Pardis Sabeti, M.D., Ph.D.

Malaria, a tremendously successful pathogen that is responsible for more than 300 million cases and 1 million deaths annually, ${ }^{1}$ has had a large impact on the shape of the human genome. Malaria- selected mutations in human genes promote survival in areas where malaria is endemic. The parasite's substantive effect on the human genome is due to its high prevalence in areas where it is endemic and its long history of coevolution with humans. Moreover, its marked genetic diversity, generated by its sexual stage, provides the organism with many opportunities to maximally adapt to host defenses and continue transmission. In this issue of the Journal, Ayi et al. ${ }^{2}$ describe a polymorphism that is hypothesized to provide resistance to malaria infection.

Why is the study of pathogen-selected host polymorphisms useful? It provides insight into naturally occurring mechanisms of host defense, which could be used to develop therapeutic agents to combat disease. Often, host polymorphisms occur in multiple genes, and their combined effect on resistance to disease presents an analytical challenge that requires the development of methods that can also be applied to other complex genetic scenarios. Finally, the role of host factors needs to be considered in the evaluation of therapeutic interventions and to refine models of pathogenesis.

Defense against malaria has been ascribed to many polymorphisms that have been maintained over generations (thanks to selection) in the human genome. ${ }^{3}$ Such protective polymorphisms are found in disparate genes that encode the cytokine response and erythrocyte proteins. The latter class of polymorphism hits close to home for the parasite: the erythrocyte is its most remarkable niche, where it finds shelter from host defenses and abundant substrates. The mechanisms of protection from this class of polymorphism are varied, ranging from inhibiting parasite growth to compromising the ability of the parasite to adhere to the microvasculature to promoting enhanced splenic clearance before the parasite can complete its life cycle. ${ }^{4}$ Some studies suggest that there are additional unknown genetic polymorphisms that mediate disease outcome and that each genetic mutation accounts for a small epidemiologic effect. ${ }^{5}$

The study by Ayi et al. builds on the established association between pyruvate kinase deficiency and protection from disease in a mouse model of malaria. ${ }^{6,7}$ The study shows that the extent of infection and replication of Plasmodium falciparum in vitro is significantly decreased in erythrocytes that are deficient in pyruvate kinase, as compared with that of normal human erythrocytes. Ring-stage parasites are less likely to invade pyruvate kinase-deficient erythrocytes than they are wild-type erythrocytes. Once infected, pyruvate kinase-deficient erythrocytes are more likely than wild-type cells to be cleared from the circulation by phagocytosis.

Pyruvate kinase is a glycolytic enzyme required for energy production, allowing the erythrocyte to maintain structural integrity and function. Mutations in the pyruvate kinase gene $(P K L R)$ alter protein function, resulting in nonspherocytic hemolytic anemia. Nearly 
200 different $P K L R$ mutations are associated with pyruvate kinase deficiency; the degree of hemolysis and anemia varies markedly, depending on the mutation. ${ }^{8}$

A major criticism of many genetic association studies, both in malaria and other diseases, is a lack of biologic mechanism. The study by Ayi et al., in contrast, is a study of the biologic mechanism without direct observation of an association with disease in humans. Although the biologic mechanism is considered by some to be the gold standard, testing for a genetic association would have great value. It would clinch the case for a mechanism associated with pyruvate kinase deficiency in protecting against malaria. More extensive genetic sleuthing would probably yield information about the degree of protective advantage conferred by different mutations in PKLR in different populations. The strength of protection of PKLR alleles would serve as an excellent reference by which to evaluate new alleles in other genes associated with malaria resistance, in which biologic confirmation is lacking.

More broadly, an examination of the action of selective pressure on pyruvate kinase could shed light on the history and mechanism of human resistance to malaria. Deficiency in glucose-6-phosphate dehydrogenase (G6PD), the other most common cause of nonspherocytic hemolytic anemia, also has biologic links to malaria resistance. Numerous mutations have been identified in $G 6 P D,{ }^{9}$ many of which affect the level of enzymatic activity. However, despite the considerable genetic diversity in G6PD, it appears that a single mutation that causes G6PD deficiency (approximately 12\% of enzyme activity) has been selected in many African populations ${ }^{10}$ and is associated with malaria resistance. The study by Ayi et al. sets the stage for a case-control study to test for an association between $P K L R$ polymorphisms and disease, as well as defining the global distribution of $P K L R$ polymorphisms.

From Brigham and Women's Hospital, Boston, and the Broad Institute, Cambridge, MA.

1. Breman JG, Holloway CN. Malaria surveillance counts. The American journal of tropical medicine and hygiene 2007;77(6 Suppl):36-47.

2. Ayi K, Min-Oo G, Serghides L, et al. Pyruvate Kinase Deficiency and Malaria. New England Journal of Medicine 2008.

3. Campino S, Kwiatkowski D, Dessein A. Mendelian and complex genetics of susceptibility and resistance to parasitic infections. Seminars in immunology 2006;18(6):411-22.

4. Williams TN. Human red blood cell polymorphisms and malaria. Current opinion in microbiology 2006;9(4):388-94.

5. Mackinnon MJ, Mwangi TW, Snow RW, Marsh K, Williams TN. Heritability of malaria in Africa. PLoS medicine 2005;2(12):e340.

6. Min-Oo G, Fortin A, Tam MF, Nantel A, Stevenson MM, Gros P. Pyruvate kinase deficiency in mice protects against malaria. Nature genetics 2003;35(4):357-62.

7. Min-Oo G, Tam M, Stevenson MM, Gros P. Pyruvate kinase deficiency: correlation between enzyme activity, extent of hemolytic anemia and protection against 
malaria in independent mouse mutants. Blood cells, molecules \& diseases 2007;39(1):639.

8. Zanella A, Fermo E, Bianchi P, Chiarelli LR, Valentini G. Pyruvate kinase deficiency: the genotype-phenotype association. Blood reviews 2007;21(4):217-31. 9. Cappellini MD, Fiorelli G. Glucose-6-phosphate dehydrogenase deficiency. Lancet 2008;371(9606):64-74.

10. Ruwende C, Hill A. Glucose-6-phosphate dehydrogenase deficiency and malaria. Journal of molecular medicine (Berlin, Germany) 1998;76(8):581-8. 